\title{
The co-constitution of violent death: bombs, civilian victims and material destruction in Rotterdam during the Second World War
}

\author{
Antonius C. G. M. Robben Utrecht University \\ t.robben@uu.nl
}

\begin{abstract}
Thousands of people died in Rotterdam during the Second World War in more than 300 German and Allied bombardments. Civil defence measures had been taken before the German invasion of the Netherlands in May 1940 and these efforts were intensified during the country's occupation as Allied bombers attacked Rotterdam's port, factories, dry docks and oil terminals. Residential neighbourhoods were also hit through imprecise targeting and by misfired flak grenades. Inadequate air raid shelters and people's reluctance to enter them caused many casualties. The condition of the corpses and their post-mortem treatment was thus co-constituted by the relationship between the victims and their material circumstances. This article concludes that an understanding of the treatment of the dead after war, genocide and mass violence must pay systematic attention to the materiality of death because the condition, collection and handling of human remains is affected by the material means that impacted on the victims.
\end{abstract}

Key words: air raid shelters, bombardments, death, material culture, the Netherlands, Second World War

\section{Introduction}

At around noon on 31 March 1943, Corrie Ponjee had just left school when she saw condensation trails of Allied planes flying above Rotterdam, the large port city in the Netherlands that had been occupied by Nazi Germany in May 1940. The air raid sirens went off, and she decided to run home along the Mathenesser Road. In a letter of April 1943 she told her pen pal Bep that she had been scolded by her mother for not entering a public shelter. 'You know, Bep, I find those air raid shelters horrible. You are so locked in and you can't see anything. I rather see what's happening in the sky. Then I'm not afraid, strange isn't it? There are never bombardments during the day. "Those are flyovers going to Germany," people say. ${ }^{1}$ Once she was home, the all-clear sounded, but soon the warning siren was heard again. Corrie and her mother put on their coats and hid near the chimney, holding their dog on a leash. 
The whistling sound assured them that the bombs were passing over their house, but several blocks on the Mathenesser Road were already on fire. Days later, Corrie returned to school and learned that many children had died in the bombardment.

Corrie Ponjee's experience was shared by many inhabitants of Rotterdam. Her account of the March 1943 bombardment reveals popular assumptions about aerial attacks and sentiments about self-protection that influenced people's behaviour when the air raid alarm sounded. Many people did seek cover, most often at home, in a cellar or below a staircase, but others preferred to watch the aerial assaults on dry docks and factories rather than to enter a public shelter. They believed that the likelihood of death was minor because Dutch civilians were not the target of Allied bombardments, unlike the German population.

The condition of the dead was influenced by the types of bombs used, the kinds of shelter available in Rotterdam and the degree of material destruction when disaster hit. The recent interest in the treatment of corpses after war, genocide and violence should therefore be extended to an examination of the materiality of violent death, because the physical condition and post-mortem handling of human remains is partly determined by the material means that extinguished life prematurely. ${ }^{2}$

Instead of taking bombs, grenades, collapsed buildings and fires spreading out of control for granted as self-evident causes of death, this article argues that an investigation of the post-mortem condition and treatment of corpses and shattered remains should pay explicit and systematic attention to the relation between people and material culture. Violent death is co-constituted by victims and artefacts because of the mutually generative forces of subjectivity and materiality. This interpretation has been inspired by an ongoing debate in anthropology and archaeology about the agency of things, objects and artefacts, also called nonhumans. ${ }^{3}$ According to Carl Knappett, 'Agency is not something we confer on objects in a one-way relationship; it emerges reciprocally as humans and nonhumans merge.4 This reciprocity does not imply an equivalence of humans and things, as Bruno Latour would have it, because artefacts do not possess intentionality or volition. ${ }^{5}$ Yet, artefacts are indispensable to give material content to people's existence, and are constitutive of the ways in which people die and how their remains will be treated.

The co-constitution of violent death and the treatment of the bodies of the civilian victims is examined here through a case study of one German and one Allied bombardment on Rotterdam during the Second World War. I will begin with a discussion of the threat of aerial warfare in the 1930s, and specify the measures taken to protect Rotterdam's civilian population. After describing the German bombardment of 14 May 1940 and the collection and treatment of the dead, I will proceed with an analysis of the fatal injuries incurred by victims of the Allied bombardment of 31 March 1943 in relation to the place of death. This article concludes that the study of the post-mortem treatment of victims of war, genocide and mass violence should extend to the material circumstances under which they died and their effects on the condition and handling of the remains. The data are derived from official wartime records and documents, local newspapers, diaries and post-war recollections, oral histories and secondary studies. These sources are used in the awareness that the 
German occupation forces controlled Rotterdam's city administration, censored newspapers and restricted the taking of photographs.

\section{Aerial bombs, bomb shelters and occupants}

Europe's fear of aerial bombardments was great after the First World War. Unsuccessful efforts were undertaken to establish international war conventions about legitimate military targets and the unlawful bombing of civilians. ${ }^{6}$ The Netherlands had been politically neutral during the First World War, and continued to pursue this strategy during the 1920 s by limiting its air force to reconnaissance capabilities. $^{7}$ Still, the chance of bombardments could not be ignored, and in 1927 the defence department asked municipalities to create Air Raid Protection Services. An urban landscape arose in Rotterdam, with air raid sirens and shelters, medical posts and anti-aircraft batteries. Blackout and fire drills became periodic reminders of the aerial threat facing Rotterdam that changed residents into a population on guard.

It was believed that gas attacks would be the most probable cause of death, but firebombing was also expected. People were advised to take shelter in a room upstairs or in an attic with an insulated roof. ${ }^{8}$ The authorities urged people to avoid seeking shelter in cellars where heavy gases would settle. Thus, domestic shelters were adjusted to the expectation of chemical and incendiary attacks but left occupants vulnerable to fragmentation bombs. Different types of bombs required different civil defence measures and protective responses from Rotterdam's inhabitants.

By 1931, bombardments with fragmentation and incendiary bombs were considered just as likely as gas bombs. Rotterdam's citizens were now encouraged to avoid attic shelters and to convert cellars into underground shelters. This switch redefined the means of survival and changed the imagination of death, now not by suffocating gases but by being crushed under tons of rubble: 'tools (pickaxes, shovels, saws) must be available to free the persons in the shelter after the entrances have been blocked by the explosions.' ${ }^{\prime}$ Underground shelters had to be made airtight against lethal gases and reinforced to withstand the kinetic impact and shock waves of fragmentation bombs.

The official instructions about how to fight spreading fires and rescue people from collapsed buildings were brief and assumed common sense, but gas bombs required specialised information about their effects. Chemical agents were classified into poisonous, asphyxiating, irritating and vesicant gases; each of which was identified by its symptoms and sensorial characteristics. ${ }^{10}$ Mustard gas was particularly feared because of the experience from the First World War: 'the affected skin becomes inflamed and red... large serum blisters ... and wounds develop that are difficult to heal. If the victim did not wear a gas mask, then there will also be nausea, vomiting, coughing, hoarseness, a burning sensation and a feeling of sand in the eyes, and redness and swelling of the eye lids. ${ }^{11}$ Rotterdam's Air Raid Protection Service was making plans for the treatment of large numbers of victims and the decontamination of houses, streets and parks. 
Germany's public announcement in 1935 of its military build-up, which included the re-establishment of the German Air Force, was a foreboding of war. The Netherlands would be unable to maintain its neutrality because its powerful neighbour was likely to invade the country in order to attack France from the north. On 23 April 1936 the House of Representatives approved a legislative proposal for the protection of civilians. Whereas in 1927, and even in 1931, the possibility of civilian casualties was regarded as unlikely, by 1936 it was assumed that in case of war, the entire civilian population will to a greater or lesser extent be seriously threatened from the air. ${ }^{12}$ Italy's use of mustard gas in the ongoing Second Italo-Ethiopian War was mentioned as an omen of what could be expected in Europe.

Rotterdam was a prime military target because of its petrochemical industries, oil terminals, dry docks and strategic importance, with its airfield, bridges across the Meuse River and extensive network of inland harbours. ${ }^{13}$ The city was slow in preparing for aerial attacks. However, the continued bombardments in Spain's civil war began to worry the authorities. By January 1939, 192 trench shelters had been dug in parks and streets. Fortunately, gas bombs had not been used in Spain, and the civil defence planning therefore began to pay particular attention to fragmentation bombs. $^{14}$

Large companies prepared basement shelters for their employees, but municipal efforts remained inadequate in 1939, according to Members of Parliament. Still, the government considered a comprehensive civil defence system to be too costly. Gas masks or domestic shelters were not issued by the Dutch authorities, unlike in the United Kingdom. ${ }^{15}$ Notably, Belgium's civil defence budget was tenfold that of the Netherlands in fiscal year 1938-39. ${ }^{16}$ People were told that they were responsible for their own protection, and could hide in public shelters only when caught in the street or if they did not have a cellar or the means to buy a domestic shelter. ${ }^{17}$

Awakened by the bombing of Warsaw in September 1939, the engineer Meulenkamp of Rotterdam's Technical Service designed a low-cost corridor shelter (Figure 1). This surface shelter was propagated as particularly suitable for Rotterdam, whose location below sea level made the construction of underground shelters difficult and expensive. The shelter consisted of slabs of reinforced concrete placed at an angle to create a tent-like structure. It was 1.9 metres high and could accommodate four seated and four standing occupants per running metre. ${ }^{18}$ Sandbags were placed at the open ends for further protection, but the shelters were still considered inadequate by experts. ${ }^{19}$ City officials claimed that by August 1939 100,000 people could be offered protection in about 200 covered trench shelters, 300 Meulenkamp corridor shelters and 100 underground shelters in public buildings. ${ }^{20}$ Nevertheless, one week before the German invasion in May 1940, a fund-raising event was held to purchase materials for the civil defence of working-class neighbourhoods. ${ }^{21}$

The slow development of Rotterdam's civil defence organisation revealed a political economy of air raid protection. The corridor and trench shelters offered limited protection and could accommodate at most one-sixth of Rotterdam's population. Death through bombing became the poor people's fate, and survival the elite's 


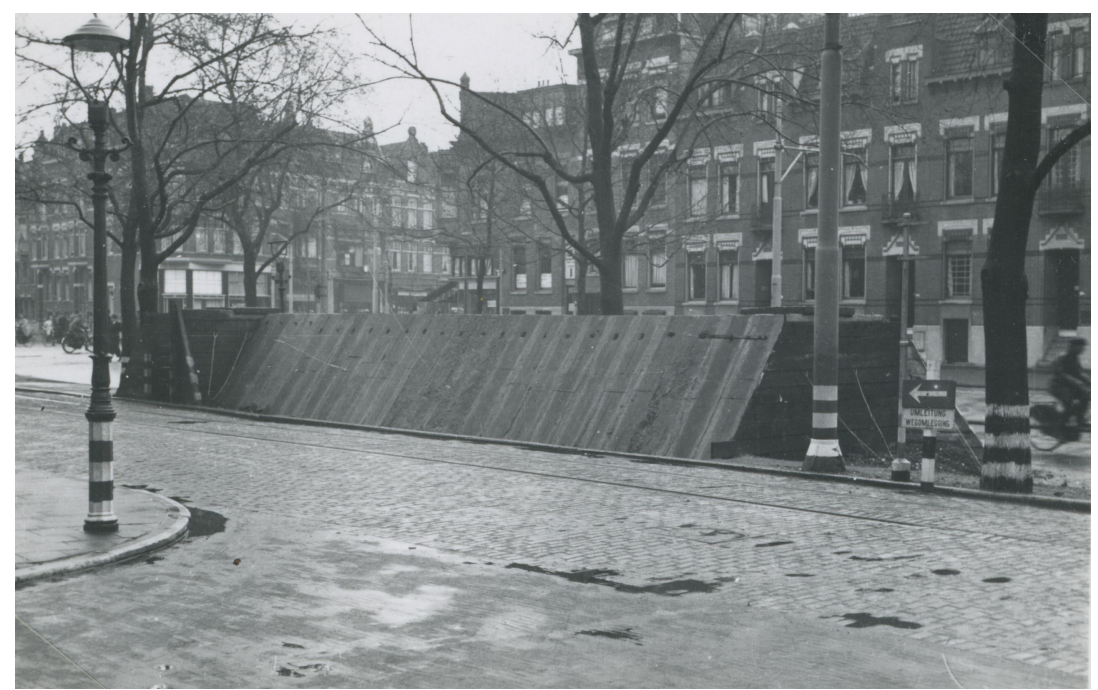

Figure 1 Corridor shelter, Henegouwerlaan, Rotterdam (Beeldbank WO2 Verzetsmuseum, Amsterdam, reproduced with permission)

privilege. Death was thus an outcome of people's choice among the limited options for protection and the material qualities of the shelters accessible to them. Only a minority had the financial means to convert cellars into secure underground shelters. The majority of Rotterdam's inhabitants had to hope for the best when they sought refuge at home.

\section{The bombardment of 14 May 1940 and the collection of the dead}

The Netherlands was invaded by the German army on 10 May 1940. Rotterdam became the target of the first-ever major airborne operation. The military airfield was bombed and paratroopers occupied southern Rotterdam. The stronghold was soon reinforced by ground troops. Fierce resistance by Dutch marines prevented the German army from crossing the bridges over the Meuse River into Rotterdam's city centre. The Luftwaffe pounded the Dutch troops entrenched on the northern river bank, while the Dutch Military Air Force and the British Royal Air Force attacked German positions.

Adolf Hitler ordered his staff to undertake decisive action. On 13 May field commander General Schmidt received the following order from General Von Küchler: 'Break the resistance in Rotterdam by all means available, and if necessary threaten with or carry out the destruction of the city.'22 The next day an ultimatum was sent to Rotterdam's military commander, who requested more time. General Schmidt extended the ultimatum by three hours, but two flight formations of Heinkel bombers had already taken off from Germany. The air raid sirens in Rotterdam 
sounded at 12.45 p.m. People rushed to the public shelters or took shelter at home. The bombardment of 14 May 1940 began at 1.27 p.m. and lasted thirteen minutes. The bombers dropped 158 fragmentation bombs of $250 \mathrm{~kg}$ and $1,100 \mathrm{of} 50 \mathrm{~kg} .{ }^{23}$ At 4.20 p.m. Rotterdam surrendered unconditionally to General Schmidt. The Netherlands capitulated the next day. ${ }^{24}$

The bombardment had been devastating. The ultimatum to surrender Rotterdam had allowed too short a time to evacuate the population, and there were not enough air raid shelters. An estimated 850 civilians died on 14 May. Around 80,000 people became homeless, out of a population of $620,000 .{ }^{25}$ The material damage was also substantial: 11,000 buildings, 25,000 homes, 19 churches and 29 schools were destroyed. ${ }^{26}$ It is unknown how many people had sought refuge in the public bomb shelters or how many shelters were destroyed. The Air Protection Service could not supply any figures. ${ }^{27}$

Within half an hour of the bombardment, the dead and wounded were brought to the Municipal Bergweg Hospital in taxis, buses, trucks and handcarts. Corpses were deposited in the garden ward of the hospital's sanatorium. Seriously wounded patients who died at the hospital were wrapped in sheets and taken to the cemetery. Photographs were taken for later use, if the identity of a victim could not be established before moving them to Crooswijk General Cemetery. ${ }^{28}$ Relatives who had fled the city were expected to make enquiries about deceased loved ones upon their return, because in May 1940 there was not yet a protocol in place that systematised the identification process.

Mr Boelhouwers began pulling people from the rubble immediately after fragmentation bombs hit his neighbourhood. 'They call me a man of iron', he said fifty years later. 'I don't show any emotion, and neither do I lie awake at night. Never shed a tear, nor during the first days. As a matter of fact, you had no time for it. If you found a corpse, then you laid it down, covered it with a piece of cloth and gave someone a signal that it was there. Further down you heard moaning and calls for help. And once again you went there. ${ }^{29}$ The dead and wounded were collected as much by civilians as by the police and the Public Health Service, because the prewar civil defence preparations did not include any instructions about the collection and handling of corpses. 'The corpses are just loaded in stacks on trucks. They are also transported by the garbage truck. There are still many [corpses] under the rubble. The weather is warm, and the city is very hot because of the fires. The smell of corpses is quickly becoming terrible. It stinks like hell, wrote Alex Iburg on the day of the bombardment. ${ }^{30}$

Several improvised search crews were assembled to find bombing victims. The Public Health Service assembled the first search crew on 13 May because scores of civilians were already dying from the German bombardments since the invasion of Rotterdam on 10 May. Dirk van Veelen gathered a group of thirty unemployed men in southern Rotterdam with first-aid training. Hours after the 14 May bombardment, the crew began looking for corpses lying exposed in the streets and destroyed buildings. After working for several days of their own accord, they were told where to dig in the rubble. On one occasion the men were asked by a clergyman to search for three young maids who had taken refuge in a vault under a church. The men 
removed some rubble, opened the hot door and were hit by an intense heat and blue smother. Inside there were three girls, dead, sitting on a bench. One crew member held his breath, ran inside and tried to pull one girl out, but she had liquefied inside the overheated vault. ${ }^{31}$ The fires spreading around the city were also amalgamating rubble and human remains where people were trapped in burning homes or buildings.

The men worked during the first days without any protective gear. Even after receiving rubber boots and gloves, within days the crew of thirty dwindled to eleven. Most men could not stand the sight, smell and touch of bodies decomposing rapidly in the warm weather. Moreover, they were afraid of ptomaine poisoning, in the belief that putrefying bodies release a deadly fluid. ${ }^{32}$

When a corpse was found, its sex was determined and the location recorded. Ideally, the Public Health Service would be called to request the so-called 'black car' with its silver skull emblem to transport the corpse to Crooswijk General Cemetery. However, the available means of transportation were so scarce that collection posts were created for temporary storage of corpses. ${ }^{33}$ Victims found in the port were collected by the river police using a special net. Descriptions of the victims were written for identification purposes, and the corpses were doused with denatured alcohol to mitigate against the smell before transporting them by car to the cemetery. $^{34}$

The first ten civilian victims of the German aerial attacks on Rotterdam had been buried at Crooswijk General Cemetery on 12 May, but so many dead were arriving on 14 May that the cemetery was closed to the public and not reopened until 8 June. All the available space was needed for the hundreds of corpses. The military dead were stretched out in the chapel, and later buried in separate lots. The civilian dead were first placed in the morgue, and later also in the chapel's cellar and the hall for contaminated bodies. There were no means to preserve the bodies. The morgue was too small, there were not enough coffins and the often damaged bodies were deteriorating quickly in the heat. The decision was taken to bury the dead civilians in a mass grave without individual coffins, but often wrapped in sheets.

Many relatives were unavailable to identify their dead because they had fled the burning city, nor could they contact the cemetery to arrange for a proper burial because all communications had broken down. One city official recalled three years later that the necessary forensic data had been gathered before the mass burial took place. A personal description was made of each of the deceased, and items such as identification cards and house keys were gathered in envelopes to aid later identification. ${ }^{35}$

There existed a distinction between military and civilian casualties. They were buried in different lots and were given different funerary treatment. The Dutch military who had fallen in the defence of Rotterdam were buried on 30 May with full military honours, in the presence of Rotterdam's mayor and high-ranking Dutch and low-ranking German officers. ${ }^{36}$ Allied and German troops were buried principally at Crooswijk General Cemetery, but the German dead who had been killed 
in action were buried separately from German soldiers who had committed suicide or had been executed after a failed desertion. Mr Boelhouwers, who became a gravedigger after having collected bombing victims in May 1940, assisted at autopsies at Crooswijk General Cemetery conducted by German physicians who wanted to ascertain whether or not the deceased German soldiers had died by ingesting poison. If such was the case, then they were buried as traitors at a burial place for unidentified soldiers. ${ }^{37}$ The 851 German military graves at the cemetery were relocated immediately after the war to the German War Cemetery Ysselsteyn in the Netherlands, but the forty-four graves of dishonoured German soldiers remained at Crooswijk General Cemetery. ${ }^{38}$

According to the records of Crooswijk General Cemetery, where most war dead were buried, there was a mass grave of 561 civilians interred between 15 May and 5 June 1940. This grave included 125 unidentified dead listed only as 'man,' 'woman' or 'human being. The director of the Public Health Service decided that the mass grave could not be exhumed, both to protect the health of the gravediggers and to respect the deceased. Nor could a second mass grave be opened, where carbonised remains were buried between 21 and 24 May. A third mass grave contained twentyfive identified bodies of German civilians, buried between 21 and 24 May. They had been held captive by the Dutch authorities in a theatre that had been hit by a bomb on 14 May. Other dead civilians were buried in individual graves. ${ }^{39}$ The three mass graves still exist today. ${ }^{40}$

Unidentifiable human remains continued to be found for months during the rubble-clearance operations. On 27 July 1940 Mrs van Ouwerkerk-Boerlage was walking through the city when she saw people standing around a few rubble workers. 'I went to see what was going on. I saw a tin pan being taken out of the rubble with, in it, a tangle of white scorched bones. These were the human remains of people who had lost their lives on the 14th of May in that hell of fire. I asked one of the rubble clearers: "Of how many people do you think this is? Oh, 20 to 25, it's impossible to determine, it's sometimes already on our wagon before we know it." '41 The remains were taken to Crooswijk General Cemetery.

Bombing victims were buried at random if the relatives were not present to arrange for an individual burial. Requests were therefore made during the war for the reburial of hastily interred bombing victims. The decision about whether or not to honour a request reveals the official concern about the dead. In May 1942 a mother asked Rotterdam's mayor for the reburial of her son who had been interred in Crooswijk's largest mass grave without the family's knowledge. In a confidential internal document the request was denied: 'Opening this grave could not only be harmful to the health of the gravediggers, but would also be contrary to respect toward the other bombing victims. ${ }^{32}$ In the draft of the mayor's written response the mother was told: 'I am fully aware that this communication must be a serious disappointment for you, but nonetheless I want to express the hope that you will find the strength to resign [yourself] to the inevitable. ${ }^{43}$ Also in May 1942, a father asked for the reburial of his son who had died during the RAF bombardment of 28 January 1942. He wanted his son to be buried in a grave next to that of his fiancée, 


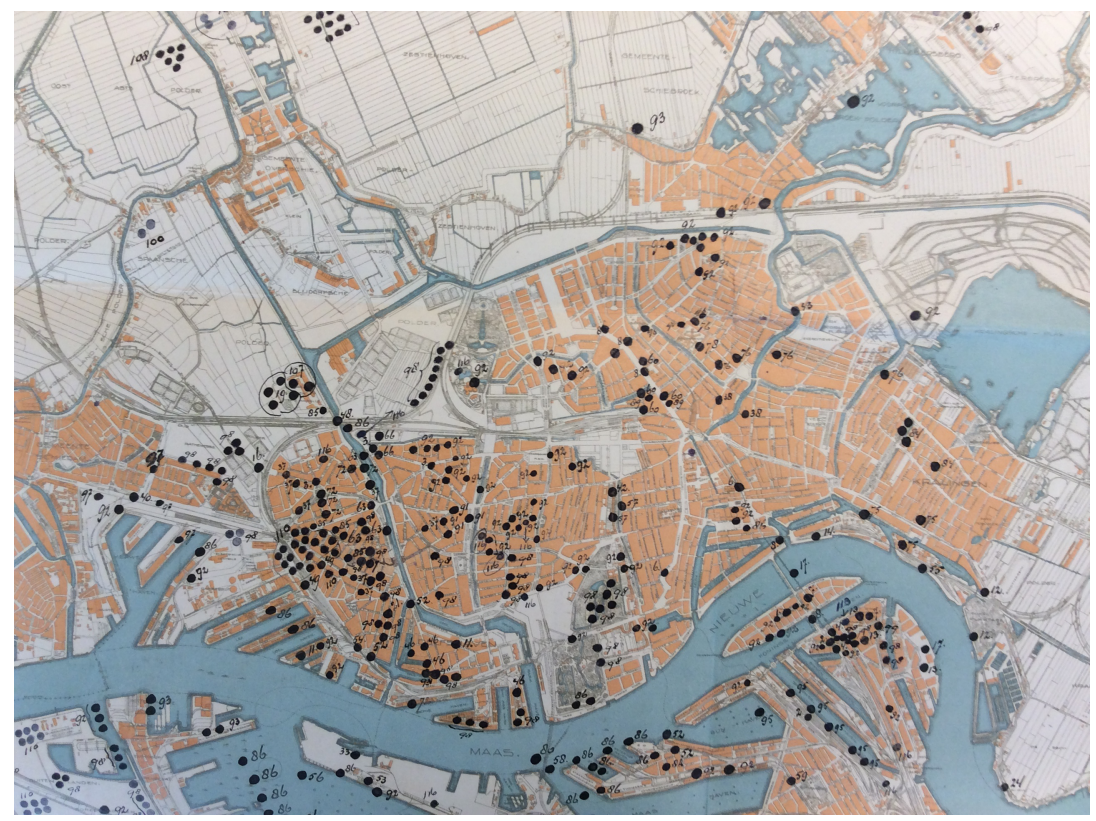

Figure 2 Map of Allied bombardments on Rotterdam from 25 May 1940 to 21 February 1945 (Photo: A. C. G. M. Robben, Rotterdam City Archive)

who was in a family grave together with five relatives who had also died on that day. The request was honoured. ${ }^{44}$

\section{The co-constitution of death at the bombardment of 31 March 1943}

The human and material losses continued unabated during the remaining five years of the war, when British and American planes attacked Rotterdam with 315 bombardments (Figure 2). ${ }^{45}$ About one half of the bombs hit the extensive port with its inland harbours, but residential neighbourhoods were damaged as well. As a result, more public air raid shelters were built. In November 1940 there were 194 trench shelters and 295 Meulenkamp corridor shelters. ${ }^{46}$ By October 1941 the number of corridor shelters had increased to 526 , available to 32,700 persons, with 60 still under construction. By mid-January 1942, 54,300 persons would be able to find refuge in the Meulenkamp shelters. ${ }^{47}$ Nevertheless, 1,029 civilians died as a result of Allied bombardments during, 27 persons died from exploding anti-aircraft grenades, and 42 persons were killed on 18 March 1945 when a German V-1 missile crashed into northern Rotterdam. ${ }^{48}$

The bombardment of 14 May 1940 had exposed the shortcomings of the Air Protection Service, and the German authorities reorganised it thoroughly in October 1940. The new service consisted of a core group of 1,200 men, of who most 
were demobilised Dutch soldiers. They complemented the understaffed police, fire department, Public Health Service and Clearing and Reconstruction Service. By 1 November 1944 the civil defence organisation had expanded, with 14,500 volunteers in Greater Rotterdam. ${ }^{49}$ Bloc wardens and their twelve volunteers were responsible for providing first aid, extinguishing fires and notifying the Central Command Post. The Post dispatched an accident location commander, generally an Order Police inspector, and informed the nearest medical post. This commander took charge and requested further assistance from the fire department, the bomb disposal squad or the water company. ${ }^{50}$ Personnel from the nearest medical post would assist the bloc team in caring for the wounded and the dead. ${ }^{51}$

The collection, identification and registration of the dead of the May 1940 bombardment had been improvised, but by 1943 printed forms were available to register the dead, wounded and missing. At the site of the accident medical personnel attached a tag to the big toe of the dead or seriously wounded person, with the location and possibly the victim's home address. A receipt was written by the Order Police for personal belongings found near the corpse that could be claimed by close relatives (e.g., golden ring and handkerchief, pocket watch with chain, mechanical pencil). ${ }^{52}$ Occasionally, only a piece of clothing was found when a victim had been forced three, four and even seven metres deep into the bomb crater. ${ }^{53}$

The dead were sometimes brought to a hospital, but generally went to Crooswijk General Cemetery. An officer from the Criminal Police visited the hospital or cemetery and tried to identify the person from the tag and the personal documents found on the body. If fingerprints could be taken, then they were matched with the identity papers. The officer filled out the forms for identified and unidentified corpses and sent the names, addresses and identity numbers to Civil Affairs for verification. After the officer had completed the identification process, relatives were granted just one occasion to see the body and arrange for the funeral. ${ }^{54}$

In the May 1940 aerial assault Rotterdam's inhabitants had experienced the force of fragmentation bombs. Their destructive effects were enhanced when the Allies began to combine fragmentation with incendiary bombs. Around 7,000 fragmentation and 42,000 incendiary bombs were dropped on Rotterdam during five years of war. ${ }^{55}$ Whereas the Allies' fire-bombing of German working-class neighbourhoods was deliberate in order to cripple the German war industry and lower morale, we can only assume that the bombing of Dutch workers was accidental. ${ }^{56}$ People generally accepted the collateral damage as the price of freedom, but they also believed that the bombing of residential neighbourhoods was due to Rotterdam's being a freshman's target. The Meuse River running through the city was easy to find for rooky pilots crossing the North Sea to the Dutch coast. ${ }^{57}$ Be this as it may, the deadliest Allied bombardment was not caused by inexperience but by poor marksmanship under adverse weather conditions.

Six bomb groups of the United States Army Air Forces intended on 31 March 1943 to attack the Wilton-Feijenoord shipyard, which produced naval vessels, torpedo tubes and U-boat engines for the German navy. ${ }^{58}$ The planes first headed towards Dunkirk, then returned to England in a diversionary loop to mislead the German air defence, and finally flew north along the coast towards Rotterdam. 
Four groups aborted their mission because of the overcast weather conditions. Two groups decided to continue. Ten minutes after the sounding of the air raid siren and a brief break in the cloud cover, the planes released 198 fragmentation bombs of 1,000 lbs, but no incendiary bombs. The planes were off course. Most bombs of the first group fell on farmland and a few houses, killing ten persons. The second bombing group misidentified its target, aiming in fact at two inland harbours east of the Wilton-Feijenoord shipyard. The bombs were dropped without precision from an altitude of 7,500 metres, despite a strong north-westerly wind. Making things worse, a west-southwesterly gale at a lower altitude blew the deadly load towards the residential neighbourhoods of Bospolder and Tussendijken, and the adjoining Marconi, Taanders and Mathenesser squares. ${ }^{59}$

The fire spread rapidly in stormy winds of force 8 to 10 on a cold spring day when stoves had been lit in most houses, and gas lines were ruptured. The furniture dragged into the street on German orders or by inhabitants wanting to save it from the spreading fire added only more fuel to the roaring inferno. On top of all this, the water pressure was so low that water had to be drawn from quite a distance at the Schie River and two harbours. The fire was finally brought under control at 11.00 p.m., almost ten hours after the bombardment. ${ }^{60}$

The response by the German and Dutch authorities had been poorly coordinated. Members of the German navy had evacuated houses threatened by fire, often against the wishes of the Dutch police. German officers also ordered Rotterdam's Technical Emergency Assistance Service to dynamite burning houses, while the Dutch Command Centre had already forbidden such a drastic measure. In its meeting of 10 April 1943 Rotterdam's Air Raid Protection Service concluded: 'As a result, people fled far too quickly from their homes. If they would have stayed longer, then many [fires] could have been extinguished. Also, the removal of furniture from houses which often were not yet in danger was not always done in a sensible way...Fight as long as possible against the flames, keep the windows shut as long as possible, and if they pop, then above all tear off the curtains. ${ }^{\prime 61}$ Rotterdam's Fire Department reported that 2,600 homes had burned down completely.

The precise number of dead from the bombardment has never been established conclusively, and probably never will be. There were unregistered men living in Rotterdam to escape forced labour in Germany, Jewish inhabitants were hiding from deportation and not all missing persons were reported. The number of victims has been estimated by different sources at 326, 341, 401 or 417 dead. ${ }^{62}$ Rotterdam's city archive contains the original corpse registration forms of 349 confirmed dead, namely 305 identified corpses and 44 unidentified corpses. Of the 305 identified victims, $32.1 \%$ were women, $41 \%$ were men and $26.9 \%$ were children aged under 18 years. $^{63}$

The bombardment on 31 March 1943 is the war's best-documented aerial attack, because only in 1943 was there a proper identification protocol in place. The following analysis teases from the records the co-constitution of violent death that resulted from the combination of people's hiding places, the kinds of shelter available, and the gender and social class of the victims. Table 1 shows that the majority of the women $(57.1 \%)$ and children $(74.4 \%)$ died at home, whereas men could die in 
Table 1 Deaths in different locations, Allied bombardment 31 March 1943 (percentages)

\begin{tabular}{lccrrrrr}
\hline & Home & $\begin{array}{c}\text { House (not } \\
\text { own home) }\end{array}$ & Street & Shelter & School & $\begin{array}{l}\text { Business (factory, } \\
\text { shop, café) }\end{array}$ & Unknown \\
\hline Men & 19.2 & 21.6 & 17.6 & 14.4 & 1.6 & 12.8 & 12.8 \\
Women & 57.1 & 12.3 & 8.2 & 4.1 & 2.0 & 0 & 15.3 \\
Children & 74.4 & 3.7 & 2.4 & 1.2 & 4.9 & 0 & 13.4 \\
\hline
\end{tabular}

Note: $\mathrm{N}=305 ; 125$ men, 98 women, 82 children. ${ }^{64}$

almost any place. The deaths of women and children were influenced by their social confinement to the home and by the gendered division of labour in a society that provided less protection to working-class neighbourhoods than to wealthier parts of Rotterdam.

Out of 305 identified dead, 141 (46.2\%) died at home and 42 (13.8\%) died in someone else's home. Why did so many people die in private homes? The question requires an examination of the material condition of the houses, the material culture of Dutch housing, the availability of public shelters and people's threat perceptions.

The neighbourhoods of Bospolder and Tussendijken were built between 1910 and 1930 and consisted mostly of social housing. Their poor material quality made the houses particularly vulnerable to collapse when impacted. This materiality mediated the relation between residents and artefacts, and demonstrates the coconstitution of violent death. People were vulnerable when hiding under stairways and in inner rooms, because many houses did not have cellars. Nevertheless, the March 1943 bombardment proved that it was not just the fragmentation bombs but, especially, the ensuing fires caused the greatest damage.

The inflammable construction materials and the particular design of Dutch houses are manifestations of how material culture influences war casualties. A commission entrusted in 1943 with the task of developing guidelines for urban construction in relation to civil defence concluded: 'In the Netherlands, compared to other countries in Western Europe, [houses] have always been built very light with thin walls, light flooring and large windows. ${ }^{65}$ This architecture allowed fires to spread rapidly. The commission stated that civil defence should focus on preventing fire hazards by building with fire-proof materials and constructing heavier walls and smaller windows.

Could the high percentage of victims that died at home be due to a shortage of public shelters? There were three Meulenkamp corridor shelters and eight trench shelters in Tussendijken, and eight trench shelters in Bospolder. In addition, there were six trench shelters at the nearby Marconi, Taanders and Mathenesser squares. ${ }^{66}$ As in any other neighbourhood of Rotterdam, these shelters could not provide room to all residents, but the lack of cellar shelters in the modest social housing exacerbated the problem of inadequate protection.

We cannot know if there was still room available in the public surface shelters of Bospolder and Tussendijken, but testimonies and news reports strongly suggest that 
people were reluctant to hide there anyway. There were complaints about surface shelters being dirty and wet, and that occupants had to urinate in enamel buckets during air raids. Unlike in German cities with their massive, bomb-proof flak towers, and more like in England during the Blitz, the people of Rotterdam were not eager to frequent public shelters that lacked the privacy and amenities of the home. ${ }^{67}$ There were reported cases of pickpocketing and there was the much-publicised kidnapping of a baby. ${ }^{68}$ Furthermore, the authorities told people that the public shelters were only for those caught in the street by a bombardment, because there were not enough public shelters for everyone. ${ }^{69}$

Nevertheless, even if there had been enough room in the public shelters, some people still preferred to stay outside. On 20 March 1943, at 7.15 p.m., a Saturdaynight crowd was gathered near the Luxor theatre when the air raid siren sounded. The policeman Hendrikus Salet told people to enter either the bomb shelter or the cinema, but many refused. To add force to his summons, he began collecting their identity cards, until a young man asked if he was authorised to do so. He also wanted a receipt. And then the tumult began. Insults and threats rained on the policeman: 'You don't belong to the police corps, I will make sure that you'll be fired'; 'You're looking for members of the NSB [Dutch National Socialist Movement]'; 'In Germany that man would have been shot long ago.' Later, the young man lodged an official complaint against the policeman for abuse of authority, but it was dismissed as unfounded. ${ }^{70}$

Another explanation of the large number of home casualties is that somehow Rotterdam's inhabitants had become used to the Allied bombardments. They thought they had discovered a pattern in the Allied bombing raids. Nocturnal attacks usually took place around full moon when the city was not shrouded in darkness because of the blackout, and daytime raids occurred preferably under cloudless skies. Under the popular assumption that Dutch civilians were not a military target, the witnessing of bombs hitting German installations in Rotterdam's port and the sight of hundreds of bombers flying to Germany boosted the hope of victory. Furthermore, I believe that, faced with the limited threat of death, people preferred to await fate in a meaningful place, surrounded by family members and personal belongings, rather than sitting or standing for hours in a bare bomb shelter under all kinds of weather. At home, they could also protect their possessions, because there were many instances of theft from abandoned houses.

Once people decided where to go when the air raid sirens sounded, whether to stay at home, whether to run to a trench, corridor or underground shelter, or whether to watch the bombing and the anti-aircraft defence from the street, they surrendered their lives to the materiality of bombs, grenade shells, houses, buildings and shelters. Survival, death and the physical condition of the corpses depended on the material properties of those artefacts. The type of bomb and the kind of shelter influenced the number of dead, the injuries inflicted and the state and treatment of the human remains.

Table 2 tabulates the lethal injuries incurred on 31 March 1943 by 245 of the 305 identified corpses, and shows how the types of injuries relate to where people sought cover. The injuries of sixty victims were not registered. In particular, the contrast 
Table 2 Lethal injuries in different locations, Allied bombardment 31 March 1943 (percentages)

\begin{tabular}{lccccccc}
\hline & $\begin{array}{l}\text { Home } \\
\end{array}$ & $\begin{array}{l}\text { House } \\
\text { (not } \\
\text { own home) }\end{array}$ & Street & Shelter & School $\begin{array}{l}\text { Business } \\
\text { (factory, } \\
\text { shop, café) }\end{array}$ & Unknown \\
\hline Incineration & 51.7 & 30.5 & 9.4 & 0 & 0 & 7.1 & 10.5 \\
Disfigurement & 21.2 & 8.3 & 21.9 & 8.7 & 0 & 42.9 & 36.8 \\
Head injuries & 18.7 & 33.3 & 34.4 & 65.2 & 100 & 35.8 & 42.1 \\
No visible injuries & 7.6 & 5.6 & 3.1 & 21.8 & 0 & 0 & 5.3 \\
Injuries to torso & 0.8 & 11.1 & 25.0 & 4.3 & 0 & 14.2 & 0 \\
Injuries to limbs & 05.6 & 5.6 & 6.2 & 0 & 0 & 0 & 5.3 \\
Other injuries & 05.6 & 5.6 & 0 & 0 & 0 & 0 & 0 \\
Number of corpses & 118 & 36 & 32 & 23 & 3 & 14 & 19 \\
\hline
\end{tabular}

Note: $\mathrm{N}=245$.

between people who died at home and in bomb shelters reveals the co-constitution of violent death and the differential nature of the lethal injuries. The principal causes of death at home were incineration (51.7\%), often after becoming trapped in a collapsed house, disfigurement (21.2\%) and head injuries $(18.7 \%)$ caused by falling debris. Incineration (30.5\%) and head injuries (33.3\%) were also the major causes of death in other private houses. The majority of the victims in air raid shelters died of head injuries (65.2\%) or had no visible injuries (21.8\%), having been killed by shock waves. This co-constitution of death also influenced the forensic identifications. Death by overpressure left the body's appearance intact, while incineration made identification possible only through durable personal items such as rings and keys, or maybe teeth. In other words, the fatal injuries resulted from a combination of the victim's choice of refuge and the materiality of the bombs, grenades, houses, buildings and shelters. The type of injury also affected the mortuary treatment of the remains because intact, disfigured or completely incinerated bodies resulted, respectively, in individual burials, a mass grave or no burial at all.

Corridor shelters caused many lethal head injuries, and their open entrances allowed shock waves to cause fatal organ damage. Three corridor shelters were severely damaged by the bombardment of 31 March 1943. One shelter was turned upside down by the overpressure of a bomb exploding three metres away, killing two children and crushing the shoulder and thigh bone of one boy. ${ }^{71}$ Also, the two corridor shelters of the machine factory Van Berkel's Patent were hit. Slabs of reinforced concrete fell on the occupants, killing nineteen men and three women. A tow-truck freed the trapped survivors by pulling away the collapsed concrete slabs. ${ }^{72}$ The shelters had offered employees a false sense of security, because they protected only against shrapnel from fragmentation bombs and flak grenades. Rotterdam's Air Raid Protection Service even stated on 29 April 1943 that, against all expectations, the trench shelters had withstood the bombardment better than the corridor shelters, even though shock waves had shifted the roof of one trench shelter. Still, a school teacher and twenty children had been able to crawl out unscathed. ${ }^{73}$ 
However, so many people remained unwilling to enter public bomb shelters that in May 1943 SS Lieutenant-General Hanns Rauter berated the Dutch for their 'extraordinary undisciplined behaviour' and promised to severely punish those who did not 'completely clear the streets and squares when the air raid siren sounds, and seek for cellar shelters or other protected accommodations. ${ }^{74}$ Rauter's instructions, which could be enforced at gun point, tried to coerce people into poorly constructed public shelters that were regarded as death traps when impacted, and were given in the knowledge that the German defences could not protect the Dutch population. Rotterdam's inhabitants seemed to have more trust in their own survival skills than in sitting passively in a public air raid shelter that did not inspire confidence. Nevertheless, such faith in one's own intuition could be fatal. In December 1943 a group of people flocked to a bomb shelter when the alarm sounded but not everyone entered it. Some were standing near the shelter's entrance to watch the bombardment, when a flak grenade exploded in their midst, killing ten persons and wounding five. ${ }^{75}$

\section{Conclusion}

This article has argued that an understanding of the condition and the treatment of the remains of thousands of inhabitants of Rotterdam who died during the Second World War from aerial bombardments must include an examination of the relationship between the victims and the material circumstances of their death. The fatal injuries of civilian victims were inflicted by the materiality of bombs, antiaircraft grenades, houses, buildings and air raid shelters, and influenced by gender and social class. The deaths were the outcome of people's decisions about where and whether to seek cover, the capacity, quality and kinds of shelter available and the types of ammunition used by the German and Allied militaries. Violent death was manifested in many ways, ranging from identifiable corpses that were removed with relative ease from damaged homes and given a proper burial to fragmented bodies that either fused with the rubble into a hybrid mass abandoned in a bomb crater or were buried in a mass grave. The amalgamation of organic and inorganic matter combines subjectivity and materiality into an emotionally disturbing whole. A telling example are the pieces of collapsed floors from the World Trade Center at 9/11 that compressed human and material remains into container-size blocks of twelve to fifteen tons. Relatives of the victims objected to placing these uncanny composites on display at the Memorial Museum as offensive to the human remains trapped inside. ${ }^{76}$

The example from 9/11 demonstrates that my argument about the coconstitution of violent death through the interaction of people and artefacts has a much wider application. The study of victims of war, genocide and mass violence should not be limited to the cause of death (execution, suffocation, incineration, crushing, starvation), the place of death (bombed cities, battlefields, internment camps) and their physical destruction (cremation, dismemberment, dissolution, disappearance). Attention should be paid equally to the material means that impacted on and intermingled with the victims, because the materiality of death affects the condition, collection and treatment of human remains. 


\section{Acknowledgements}

Drafts of this article were presented at the conference 'Beyond Death: Exploring the Uses of Dead Bodies, Funerary Objects, and Burial Spaces through Time' held in Vienna, Austria in May 2018, at the conference 'Bodies out of Place. Mass Violence, Mass Graves and Necropolitics: Perspectives from Forensic and Social Sciences' in Donostia/San Sebastián, Spain in July 2018 and at the Max Planck Institute in Göttingen, Germany in September 2018. I am grateful to these audiences for their perceptive observations, to Jean-Marc Dreyfus for his editorial guidance and to two anonymous reviewers whose comments helped to improve this article's focus and argument. Finally, I want to thank the front desk staff at the Rotterdam City Archive for their assistance in locating records and documents.

\section{Notes}

1 'Het vergeten bombardement', WAR (Werkgroep voor Arbeidersliteratuur), 3:1 (1978), 27.

2 See, for example, É. Anstett and J-M. Dreyfus (eds), Destruction and Human Remains: Disposal and Concealment in Genocide and Mass Violence (Manchester, Manchester University Press, 2014); F. Ferrándiz and A. C. G. M. Robben (eds), Necropolitics: Mass Graves and Exhumations in the Age of Human Rights (Philadelphia, University of Pennsylvania Press, 2015); F. Stepputat (ed.), Governing the Dead: Sovereignty and the Politics of Dead Bodies (Manchester, Manchester University Press, 2014).

3 See A. Gell, Art and Agency: An Anthropological Theory (Oxford, Clarendon Press, 1998); I. Hodder, Entangled: An Archaeology of the Relationships between Humans and Things (Oxford, Wiley-Blackwell, 2012); B. Latour, Pandora's Hope: Essays on the Reality of Science Studies (Cambridge, MA, Harvard University Press, 1999); C. Knappett and L. Malafouris (eds), Material Agency: Towards a Non-Anthropocentric Approach (New York, Springer, 2008); D. Miller (ed.), Materiality (Durham, NC, Duke University Press, 2005).

4 C. Knappett, Thinking through Material Culture: An Interdisciplinary Perspective (Philadelphia, University of Pennsylvania Press, 2005), p. 28.

5 Latour, Pandora's Hope, p. 212.

6 R. Overy, The Bombing War: Europe 1939-1945 (London, Allen Lane, 2013), pp. 20-9.

7 D. Starink, De jonge jaren van de luchtmacht: Het luchtwapen in het Nederlandse leger 1913-1939 (Amsterdam, Boom, 2013), pp. 51-2.

8 Departement van Oorlog, Aanwijzingen nopens de door burgerautoriteiten te nemen maatregelen ter bescherming van de bevolking tegen de gevolgen van aanvallen uit de lucht, IIde Afdeeling, No. 37, 9 March (The Hague, Algemeene Landsdrukkerij, 1927), pp. 21-2.

9 Departement van Defensie, Leidraad voor de burgemeesters bij het nemen van maatregelen ter bescherming van de bevolking tegen de gevolgen van aanvallen uit de 
lucht, IIde Afdeeling B, No. 61, 30 May (Breda, De Koninklijke Militaire Academie, 1931), p. 41.

10 Ibid., pp. 27-8.

11 Ibid., p. 29.

12 A. H. van Leeuwen and H. Sangster, Schuilplaatsen, en beveiliging tegen luchtaanvallen (Leiden, A. W. Sijthoff's Uitgeversmaatschappij, 1936), p. 1.

13 J. L. van der Pauw, Rotterdam in de Tweede Wereldoorlog (Amsterdam, Boom, 2006), p. 39; J. J. Baart and L. van Oudheusden, Target Rotterdam: De Geallieerde bombardementen op Rotterdam en omgeving, 1940-1945 (Amsterdam, Boom, 2018), pp. 125-9.

14 'Rotterdam en de Luchtbeschermingsdienst: Groote belangstelling voor schuilplaatsen', Rotterdamsch Nieuwsblad, 23 April 1937.

15 'Critiek op luchtbescherming', Rotterdamsch Nieuwsblad, 23 November 1939.

16 K. H. Gaarlandt and F. A. Helmstrijd, Aanwijzingen voor de organisatie van een gemeentelijken luchtbeschermingsdienst (Alphen aan den Rijn, N. Samson, 1939), p. 12.

17 Luchtbeschermingsdienst van Rotterdam, Wenken op het gebied van de luchtbescherming (Rotterdam, Luchtbeschermingsdienst, 1939), pp. 27-38;

K. Bosma, Schuilstad: Bescherming van de bevolking tegen luchtaanvallen (Amsterdam, SUN, 2006), p. 81.

18 J. J. Meulenkamp, Bouw en inrichting van schuilplaatsen tegen luchtaanvallen (Amsterdam, H. J. Paris, 1939), pp. 160-9; Bosma, Schuilstad, p. 77.

19 'Het vernietigend oordeel over de Meulenkamp-schuilgang', Rotterdamsch Nieuwsblad, 22 December 1939. Rotterdam's Technical Service had conducted a test in October 1939 which demonstrated that the Meulenkamp shelter could withstand the weight of a falling wall; see 'Het overheidssysteem van luchtbescherming', Rotterdamsch Nieuwsblad, 19 October 1939.

20 'Het overheidssysteem van luchtbescherming', Rotterdamsch Nieuwsblad, 19 October 1939; 'De schuilgangen Meulenkamp', Rotterdamsch Nieuwsblad, 12 June 1940.

21 'Luchtbeschermingsavond', Rotterdamsch Nieuwsblad, 4 May 1940.

22 Pauw, Rotterdam, p. 74.

23 Baart and Oudheusden, Target Rotterdam, p. 55.

24 L. de Jong, Het Koninkrijk der Nederlanden in de Tweede Wereldoorlog, Vol. 3, Mei '40 (The Hague, Martinus Nijhoff, 1970), p. 399; Pauw, Rotterdam, pp. 74-87;

A. Wagenaar, Rotterdam mei '40: de slag, de bommen, de brand (Amsterdam, Uitgeverij De Arbeiderspers, 1970), pp. 285-303.

25 Pauw, Rotterdam, pp. 848, 854.

26 Gemeente Rotterdam, Verslag van den toestand der gemeente Rotterdam 1940 (Rotterdam, Van Waesberge, Hoogewerff \& Richards, 1941), appendix 13.

27 Bosma, Schuilstad, p. 175.

28 P. H. Kramer, 'Het Gemeente-ziekenhuis aan den Bergweg in de oorlogsjaren (1940-1945)', Rotterdams Jaarboekje, 5:5) (1947), 219-47, at 224-31.

29 F. Baarda, Uit het hart: Rotterdammers over het bombardement (Amsterdam, Uitgeverij Focus, 1990), p. 136. 
30 A. P. Iburg, Dagboek (The Hague, Royal Library, 1940-41), p. 8.

31 Interview of Dirk van Veelen by Aad Wagenaar on 17 April 1968, 4011_GV-428-1B (CD-A 1221), Rotterdam City Archive.

32 Ibid.

33 Ibid., and 4011_GV-428-2 (CD-A 1222), Rotterdam City Archive. See also Wagenaar, Rotterdam mei '40, pp. 373-8.

34 Inv. nr. 63_940, Rotterdam City Archive.

35 'Verslag J. D. Quack, afd. Chef Gemeentewerken van GTD over de opruimingswerkzaamheden na het bombardement van 14 mei 1940, 1943, pp. 7-9. Inv. nr. 273_880, Rotterdam City Archive.

36 'Symbolische begrafenis op Crooswijk van Nederlandsche militairen', Rotterdamsch Nieuwsblad, 30 May 1940.

37 Baarda, Uit het hart, p. 140.

38 M. Kamphuis and D. Nicolas, De stad en de dood. Algemene Begraafplaats Crooswijk, Rotterdam 1828-2000 (Rotterdam, Uitgeverij De Hef, 1999), p. 101.

39 Crooswijk Cemetery records. Inv. nr. 676_186, Rotterdam City Archive. The official count of civilians from the May 1940 bombardment buried at Crooswijk Cemetery is 763, which includes the 561 dead in the mass grave (see also 'Verslag J. D. Quack', p. 9.). In addition, 57 victims were buried at the Roman Catholic Cemetery (Gemeente Rotterdam, Verslag van den toestand der gemeente Rotterdam 1940, p. 39). There were also military graves for 123 Dutch, 141 German and 3 British troops, and a Field of Honour with the remains of 52 executed members of the Dutch resistance.

40 'Slachtoffers van bombardement kregen laatste rustplaats in Vak GG', Algemeen Dagblad, 11 May 2018.

41 Memoirs of Mrs. C. van Ouwerkerk-Boerlage. Inv. Nr 273_121, Rotterdam City Archive.

42 Inv. nr. 494-01_511, Rotterdam City Archive.

43 Ibid.

44 Ibid.

45 Baart and Oudheusden, Target Rotterdam, p. 431.

46 Inv. nr. 164-01_506, Rotterdam City Archive.

47 W. G. Witteveen, 1942. 'Beknopt overzicht van de voornaamste openbare werken in 1940 en 1941', Rotterdamsch Jaarboekje, 4:10 (1942), p. lii.

48 Baart and Oudheusden, Target Rotterdam, p. 444.

49 Laban, 'Luchtbescherming', pp. 16, 20; F. A. M. van Riet, Handhaven onder de nieuwe orde (Zaltbommel, Aprilis, 2008), pp. 126-7.

50 Inv. nr. 652_2, Rotterdam City Archive.

51 Laban, 'Luchtbescherming', p. 18.

52 Records of the dead of the 31 March 1943 bombardment by the United States Army Air Forces: inv. nr. 63_3275 and inv. nr. 63_3276. Receipt: inv.nr 63_4338, Rotterdam City Archive.

53 Inv. nr. 63_1030, Rotterdam City Archive. A. Korthals Altes, Luchtgevaar: Luchtaanvallen op Nederland 1940-1945 (The Hague, Sijthoff, 1984), p. 165. 
54 'Organisatie der identificatie van de bombardementsslachtoffers en inrichting van een inlichtingenbureau', inv. nr. 63_4339. 'Instructie voor de rechercheurs, belast met de identificatie van getroffenen door bominslag', 15 January 1942, inv. nr. 63_4339, Rotterdam City Archive.

55 Baart and Oudheusden, Target Rotterdam, p. 431.

56 Overy, The Bombing War, p. 259.

57 B. Laurens, Rotterdam 1941: Dagelijks leven en Engelse bommen (Rotterdam, Ad. Donker, 2005), pp. 22-5.

58 Baart and Oudheusden, Target Rotterdam, pp. 269-70.

59 Ibid., pp. 270-4, 290; Korthals Altes, Luchtgevaar, pp. 160-1; Pauw, Rotterdam, pp. 379-81.

60 Typescript 'Verslag bestrijding bombardement Rotterdam 31 March 1943', http://nationaalbrandweerdocumentatiecentrum.nl/wpcontent/uploads/2015/01/1943-verslag-bestrijding-bombardement-rotterdam-31maart.pdf [Accessed 22 June 2018]; Baart and Oudheusden, Target Rotterdam, pp. 279-82; inv. nr. 63_1030, Rotterdam City Archive.

61 Inv. nr. 497_47-48, Rotterdam City Archive.

62 A. Wagenaar, Het vergeten bombardement (Rotterdam, Stichting Ons Rotterdam, 2003), p. 27; Kamphuis and Nicolas, De stad en de dood, p. 100; Pauw, Rotterdam, p. 847; Baart and Oudheusden, Target Rotterdam, p. 284.

63 Records of identified and unidentified corpses of 31 March 1943, inv. nr. 63_3275 and 63_3276; Information cards of missing persons, inv. nr. 63_4336, Rotterdam City Archive.

64 Records of the identified corpses of 31 March 1943; Inv.nr. 63_3275, Rotterdam City Archive.

65 'Stedebouwkundige en bouwtechnische richtlijnen in verband met de luchtbescherming', typescript, December 1943, p. 3; Inv. nr. 653_5, Rotterdam City Archive.

66 Inv. nr. 63_932, Rotterdam City Archive.

67 A. Calder, The People's War: Britain 1939-45 (London, Jonathan Cape, 1986), pp. 179-81; K. Mallory and A. Ottar, The Architecture of War (New York, Pantheon Books, 1973), pp. 229, 249.

68 'Een verachtelijke daad', Rotterdamsch Nieuwsblad, 19 November 1942; 'Twee moeders betwisten elkaar een kind', Rotterdamsch Nieuwsblad, 17 June 1940.

69 'Openbare schuilgelegenheden', Rotterdamsch Nieuwsblad, 28 November 1940.

70 Inv. nr. 63_1030, Rotterdam City Archive.

71 Typescript 'Hulpverleening bij het laatste bombardement van Rotterdam', 30 April 1943, inv. nr. 273_1460; inv. nr. 63_1030, Rotterdam City Archive.

72 Wagenaar, Het vergeten bombardement, p. 15.

73 Inv. nr. 63_1030, Rotterdam City Archive.

74 'Houding van bevolking bij luchtalarm', Rotterdamsch Nieuwsblad, 1 May 1943.

75 'Zoek dekking bij luchtalarm', Rotterdamsch Nieuwsblad, 30 December 1943.

76 F. Torres, '9/11: Absence, Sediment, and Memory', in F. Ferrándiz and A. C. G. M. Robben (eds), Necropolitics: Mass Graves and Exhumations in the Age of Human Rights (Philadelphia, University of Pennsylvania Press, 2015), pp. 141-57. 